\title{
MEMORANDUM CONCERNING THE DEFERMENT OF GRADUATE STUDENTS, TEACHERS, AND RESEARCH WORKERS IN PHYSICAL SCIENCE
}

On November 26 two important changes in Selective Service regulations were announced. These fundamentally affect the situation with respect to the deferment of graduate students and teachers of physical science and engineering.

Local Board Memorandum No. 115 is amended so as to read: "A registrant age 18 through 25 may be retained or placed in Class II-A if the local board finds that he is necessary to and regularly engaged in an activity in the support of the national health, safety or interest." This is a liberalization of the previous Memorandum 115 for the requirement that the registrant be "indispensable and irreplaceable" is dropped. Form 42A (Special-Revised) will continue to be used for the making of requests for the occupational deferment of registrants ages 18 through 25 , except those found to be disqualified for any military service or found to be qualified for limited military service only. For this latter group, Form 42 should be used.

Memorandum 115-M, which is reproduced in full and attached to this communication, concerns special consideration for certain students, teachers and research workers in the physical sciences. This memorandum represents a recognition by Selective Service of : (1) the shortage of scientific personnel, due to the curtailment of advanced study in science during the war; (2) the necessity for the resumption of study in these fields.

Selective Service officials believe that these two memoranda, 115 and $115-\mathrm{M}$, adequately provide for the deferment of scientific and technical personnel. Cases now active where registrants seem to have been improperly classified should be reopened at once in the light of the new releases. In view of the change in policy, it is advisable that the department chairman request re-consideration of such cases.

T. H. HILDEBRANDT, President

J. R. KLINE, Secretary

December 10, 1945. 
LOCAL BOARD MEMORANDUM NO. 115-M. ISSUED: $11 / 26 / 45$

SUBJECT: SPECIAL CONSIDERATION FOR CERTAIN STUDENTS, TEACHERS, AND RESEARCH WORKERS IN THE PHYSICAL SCIENCES

Part I-Statement of GeNeral POLICIES AND PROCEDURES

1. General.-The demands of the armed forces and industry during the emergency have resulted in a curtailment in advanced studies for men having high technical and scientific qualifications. Since the cessation of active fighting, the demands of long range national interest require a resumption of these studies in order to fully develop the technical and scientific skills which have been acquired and to provide adequate teaching facilities for returning veterans who desire to resume their studies in these fields.

2. Reconversion working committee on deferment and selective release.-(a) Pursuant to a request from the Director of War Mobilization and Reconversion, the Reconversion Working Committee on Deferment and Selective Release has been established to assist in the accomplishment of this purpose. The Committee is composed of representatives of the (1) Office of Scientific Research and Development; (2) Civilian Production Administration; (3) Office of Rubber Reserve; (4) Petroleum Administration for War; (5) War Department; (6) Navy Department; (7) United States Employment Service; (8) Office of Education; (9) National Roster of Scientific and Specialized Personnel; and the (10) Selective Service System. The Chairman of the Committee will be the Director of War Mobilization and Reconversion, or a staff member designated by him. The functions of the Committee are to:

(1) Indicate to the Director of War Mobilization and Reconversion the specific occupations in which shortages of personnel threaten to interfere with the national health, safety, or interest.

(2) Formulate the specific standards indicating that a man is qualified to engage in a selected occupation.

(3) Certify to the Director of the Selective Service System those individuals meeting the standards established by the Committee.

(4) Indicate to the War and Navy Departments the categories of occupations in which shortages detrimental to the national interest could be relieved by release of men from the armed forces.

\section{PART II-CERTIFICATION PLAN}

1. Operation of plan.-The Director of the Office of War Mobilization and Reconversion will examine all proposals by the Committee relating to deferment and release, and shall transmit to the Selective Service System and the War and Navy Departments all approved proposals. The Director will transmit the recommendations for deferment to local boards through the appropriate State Directors. 
2. Classification policies.-Pursuant to the provisions of this memorandum and under the general authority contained in paragraph 5 of Part II of Local Board Memorandum No. 115, as amended, local boards will give serious consideration to the occupational deferment of registrants engaged in the technical and scientific fields set forth in Part III of this memorandum.

\section{PART III-STANDARDS AND PROCEDURES}

1. Advanced studies in the physical sciences or engineering.-(a) Any registrant who is accepted by an accredited college or university as a candidate for a Master's or Doctor's degree in the physical sciences or engineering may be certified by the Office of War Mobilization and Reconversion to the Director of Selective Service as essential to the national interest in a civilian capacity.

(b) The fact that a candidate for a Master's or a Doctor's degree may engage in part-time employment or other activities will not affect his certification under this paragraph so long as his academic standing is satisfactory.

2. University teaching in the physical sciences or engineering.-Any registrant who is to be employed by an accredited college or university as a teacher of physical sciences or engineering may be certified by the Office of War Mobilization and Reconversion to the Director of Selective Service as essential to the national interest in a civilian capacity.

3. University research in the physical sciences or engineering.(a) Any registrant (1) who is to be employed by or attached to the staff of an accredited college or university for research in the physical sciences or engineering and (2) who signifies his intention to engage in such an activity may be certified to the Director of Selective Service as essential to the national interest in a civilian capacity.

(b) Such a registrant will be certified only if (1) the research to be undertaken by the registrant contributes significantly to the national interest, and (2) inability of the individual registrant to undertake the research will result in its delay.

4. Submission of information in certain cases.-Any registrant who wishes to be certified under the provisions of paragraphs 1, 2, and 3 above, must present to the Office of War Mobilization and Reconversion, Washington, D. C., the following documents in triplicate:

(a) A notarized statement of his intention:

(1) To undertake graduate studies leading to a Master's or Doctor's degree in the physical sciences or engineering; or

(2) To engage in the teaching of physical sciences or engineering; or

(3) To undertake advanced research in the physical sciences or en- 
gineering on the staff of or attached to a college or university.

(b) A statement from an accredited college or university signed by a responsible official of the college or university, indicating that the registrant:

(1) Has been accepted as a candidate for a Master's or Doctor's degree in the physical sciences or engineering; or

(2) Has been accepted as a teacher of physical sciences or engineering; or

(3) Is to be employed by or attached to the staff of the college or university for research in the physical sciences or engineering, together with a statement indicating in detail the nature of the research to be performed by the registrant, the scope of the registrant's responsibilities for the research, and the necessity for securing the individual registrant for the work.

(c) A statement showing the registrant's name, address, age, Selective Service local board number and address, classification, and educational qualifications.

5. Study leading to a B.S. or B.A. degree in physical sciences or engineering.-(a) Any registrant who has satisfactorily completed at least three years of work leading to a Bachelor's degree in the physical sciences or engineering may be certified by the Office of War Mobilization and Reconversion to the Director of Selective Service as essential to the national interest in a civilian capacity, provided such registrant has served for a period of not less than two years in a project directly connected with the war effort.

(b) Any registrant who wishes to be certified under the provisions of this paragraph must present to the Office of War Mobilization and Reconversion, Washington, D. C., the following documents in triplicate:

(1) A notarized statement of his intention to continue undergraduate studies leading to a B.S. or B.A. degree in the physical sciences or engineering.

(2) A statement from an accredited college or university, signed by a responsible official of the college or university, indicating that the registrant has been accepted for the fourth year of study in a course leading to a B.S. or B.A. degree in the physical sciences or engineering.

(3) A statement showing the registrant's name, address, age, Selective Service local board number and address, classification, and educational qualifications.

(4) A statement from the registrant's employer that he has been engaged for at least two years in scientific war work.

Lewis B. HeRshey, Director 